TECHNICAL TRANSACTIONS 9/2018

CIVIL ENGINEERING

DOI: $10.4467 / 2353737$ XCT.18.133.8972

SUBMISSION OF THE FINAL VERSION: 13/8/2018

\author{
Stanisław Belniak \\ belniaks@uek.krakow.pl \\ Katarzyna Kania \\ kaniak@uek.krakow.pl \\ Institute of Real Estate Market, Cracow University of Economics
}

\title{
DETERMINANTS OF LAND DEVELOPERS' ACTIVITY IN POLAND
}

\section{Determinanty DZIAŁALnośCI LAND DEWELOPERSKIEJ W POLSCE}

\begin{abstract}
The proper use of space, particularly in urban areas, has become very important. Land developers are focused on activities which increase the value of land by preparing it for investment (the purchase of land, transforming it into the building area, merging or division of land into smaller parcels, utilities, and the final sale to other developers). In this article, land development activity is also considered as part of the development process. The aim of this study is to identify the factors that determine the manner of activities related to the procurement and preparation of land for construction by developers. The research is an important step towards the creation of the concept of land developers' activity in Poland.
\end{abstract}

Keywords: land developer, development project, land use, land development

\section{Streszczenie}

Obserwując zmiany zachodzące w zagospodarowaniu terenów w Polsce, można stwierdzić, że duży udział tych przemian wynika z działalności deweloperskiej. W długim okresie działania deweloperów wymuszają istotne przeobrażenia gruntów. Z kolei grunty jako kapitał stanowią zasadniczy element gospodarki rynkowej I, co najważniejsze, są zasobem ograniczonym. W Polsce aktywność deweloperów obserwowana jest głównie na rynku nieruchomości mieszkaniowych. To powoduje, że często przez pryzmat tej działalności definiuje się dewelopera, traktując go jako przedsiębiorstwo budujące mieszkania na sprzedaż. Rozwinięte rynki nieruchomości wyróżniają deweloperów działających zarówno w segmencie nieruchomości mieszkaniowych, jak i komercyjnych (biurowe, handlowe, magazynowe itp.), ale także zajmujących się tylko przygotowaniem gruntów pod przyszłą zabudowę. W Polsce dotychczasowe czynniki rynkowe nie wymusity aż tak daleko idącej specjalizacji działalności deweloperskiej. Dlatego wachlarz usług świadczonych przez deweloperów jest dość szeroki. Celem artykułu jest identyfikacja czynników mających wplyw na przeobrażanie i przygotowanie gruntów przez deweloperów. Przeprowadzone badania są częścią tworzenia koncepcji działalności land deweloperskiej.

Słowa kluczowe: land deweloper, projekt deweloperski, zagospodarowanie terenu, planowanie przestrzenne 


\section{Introduction}

Analysing the changes in land use in Poland, it can be observed that a large share of these changes results from developers' activity. In addition, land as capital is an essential part of the market economy and most importantly, it is a limited resource. Therefore, the proper use of space, particularly in urban areas, is becoming important. Land developers are focused on activities which increase the value of the land by preparing it for investment (the purchase of land, transforming it for building, merging or division of land into smaller parcels and utilities, and the final sale to other developers). In a development project, land is the key factor of production. Issues relating to its identification, selection and development are fundamental during the pre-investment phase. Changes in the property market force developers to professionalise their operations by, among other strategies, making rational use of land resources. The aim of this study is to identify the factors that determine the manner of activities related to the procurement and preparation of land for construction by developers.

\section{Literature review}

Property development is an extremely complex activity that involves significant numbers of people and skills, using extensive resources over an extended period for the provision of physical buildings in the future. It all starts with the provision of development land. Many studies relevant to developers' activities of land conversion apply to property using opportunities (e.g. real option in American literature) are increasingly being promoted in the academic world for use by developers to make more informed decisions on the timing of property development and the valuation of development land [14]. A real option is valuable in an uncertain economic environment because foregoing development today preserves the opportunity to develop at a later date when additional information is available. Option pricing models built around the basic concept have been used in literature on property development to evaluate: the conversion of land on the urban fringe [1]; time lags between production decisions and the delivery of news pace to the market [13]; flexibility in the timing and intensity of development [20,3]; information asymmetries [10, 4]. Thus it is worthy of attention in spite of the world of uncertainty and imperfect information. Previous studies mainly based on the financial side of the decisions by developers. In contrast, there are few studies in the literature concerning land conversion issues in the context of the decisions made by developers or land developers. In particular, it seems an interesting area of research in Poland because in recent years, planning laws have allowed developers a reasonable amount of freedom with regard to shaping land use [16].

The importance of the developer in land development models has been extensively analysed my many researchers in previous studies. One of these is the model devised by Drewett [6] who argued that in understanding the land development process, attention should be placed on the developers because they are central to the development process. Drewett shares the idea with some earlier analysts such as Craven [8] and Kaisser and Weiss [11] who 
argued that the developer is the key coordinator and catalyst for development, whose actions are triggered by perceptions of potential yields. McNamara [16] attempted to incorporate the time factor into a general description of the development process. He further developed this idea into a classifications of developers' interests according to the timescale of their involvement in a development project. An alternative approach was taken by Goodchild and Munton [9] who devised a general model of the land development process based upon two key decision points: the identification of land as being suitable for development; the initiation of construction work upon that land.

\section{Metodology}

This article is a part of research which was conducted to develop a wider project [12] at the same title. The theoretical part of the elaboration allows identification of the determinants which have an influence on land developers' activity through the application of a survey questionnaire. The survey was conducted among developers who were members of the Polish Union of Real Estate Development Companies. The survey method was aimed at determining the impact of individual factors on land developers' activity in Poland. Here, a Likert scale [15] was applied, where five possible answers were specified, ranging from 'no influence' to 'very big influence' The respondents could express the importance of a selected factor by choosing one of the following answers: 1 - no influence, 2 - slight influence, 3 - average influence, 4 - big influence, 5 - very big influence.

\section{The essence of land developers' activity}

In Poland, developers' activity is mainly observed in the housing market. This means that a developer is often defined as a company that is building apartments for sale. Developed property markets distinguish between developers working in both the residential and commercial sector (office, retail, warehouse, etc.) and land developers. In Poland, the current market factors have not applied such clear-cut distinctions so in this article, land development activity is also considered as a part of the development process. In literature, the term 'land developers' activity' is referred to as development activity leading to transformation of land including: acquiring the land; increasing its value though land conversion; consolidation and division; preparation for a construction project; development of amenities; selling the plots of land at a profit $[5,18]$.

Such an approach to land developers' activity applies to the conversion of land from agricultural to residential use. In the author's opinion, this is one of the possibilities for running a land development project and it is assumed that land developers' activity is a special form of investment activity which is focused on the development/conversion of land which could be targeted for construction in the future. This approach considers the possibility of conducting land developers' activity not only with agricultural land but also with brownfields, 
devastated and degraded land or land that is treated as wasteland. This argument seems to be particularly important for reducing urban sprawl and for the implementation of investment projects according to sustainable development rules.

\section{Factors influencing land development activity}

The determinants of land developers' activity are considered as factors that make up the external environment in which developers carry out activities related to the preparation of land for construction projects. They also include internal factors influencing developers' decisions and kind of activities carried out on land. The external determinants are understood as the environment in which a developer/land developer operates. Internal factors are divided into two groups - those which depend upon conditions relating to the given company and those which depend on the characteristics of potential land for investment and there is indicative of criteria for the decision to purchase and to prepare it for construction. A graphical portrayal of the proposed scheme is shown in Fig. 1.

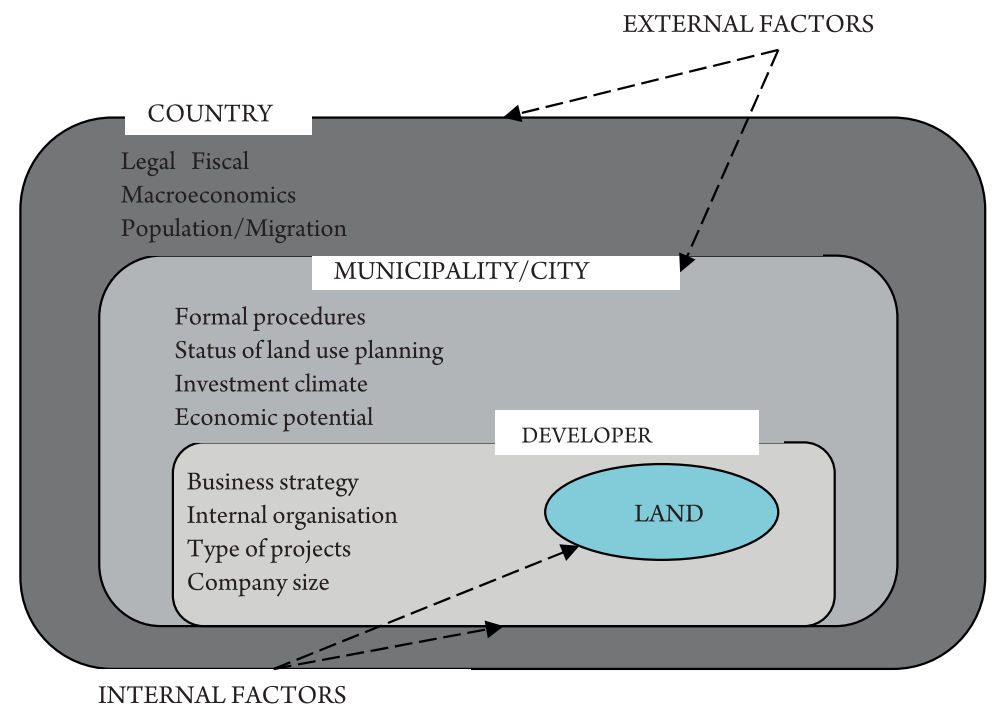

Fig. 1. Determinants of land developers' activity in Poland - conception (source: own study based on the research [12])

The external environment creates certain conditions, the form and influence of which on business is independent and companies often have to submit to them in their activities. The external factors were divided into two groups. In the first group are the conditions observed at country level, such as the legal, fiscal, macroeconomic, demographic determinants. The second group includes factors at the municipality/local level and these are the legal procedures imposed by officials, the planning system, the investment climate and the economic potential. 
The group of determinants influencing the land business at country level includes:

- legal conditions of the investment process,

- economic situation in the property market,

- fiscal conditions,

- transaction costs,

- macroeconomics,

- external financing conditions.

The determinants influencing land developers' activity at a local level include:

- land use planning system,

- implementation of the procedures by officials,

- planning fee,

- investment climate,

- economic potential of the area,

- land supply,

- local community,

- ownership.

The list of selected factors was supplemented by two more:

- migration,

- competition among developers

In the author's opinion, these factors can be analysed at the national or municipality level. This depends on whether the development company is running on the local or the national property market.

In order to determine the influence of factors on searching, acquiring and preparing the land for construction, internal factors (depended on the company) were selected. The following factors were included:

- business strategy including creation of land bank, type of development project,

- type of action for preparing land,

- business organisation including number of employees, having expansion division, the way of cooperation with company preparing land,

- legal form (e.g. limited liability company etc.),

- company experience.

Due to specific and individual nature of land, it was necessary to create a second group of internal factors to define the physical characteristics of the land to be developed. These factors are as follows:

- size,

- amenities,

- shape,

- access to public road,

- buildings to be demolished,

- neighbourhood/surrounding area,

- soil contamination and remediation. 
Economic and legal conditions are:

- legal status,

- location,

- type of construction,

- potential allocation in land use plan or planning permission.

Internal factors include the following actions which focus on the preparation of land for building projects:

- consolidation and division,

- obtaining the zoning decision.

\section{Results of empirical research}

The respondents' answers show that all analysed conditions have an impact on the activities that land developers conduct. The average response for all determinants is 3.47 and this means that there is more than a moderate impact of external determinants on the process related to the final preparation of land for building investment projects.

Analysis of the impact of individual determinants was performed according to the aforementioned classification. Among the characteristics observed from the national perspective, the legal conditions of the investment process had the highest rate (4.41). It is worth adding that over 55\% of respondents rated the influence as very big, and over 33\% rated it as big.

The economic situation on the property market was rated as 3.96 and this was the second highest rating. Almost $30 \%$ of respondents recognised it as being very important. Just over $40 \%$ of respondents indicated that the significance of this determinant in influencing land developers' activity is big.

The lowest rating (2.92) related to the influence of fiscal conditions which may suggest that tax laws have the least influence on land developers' activity of all factors at the national level. In spite of this, it should be stressed that the score for this factor was close to 3 and this confirms the strength of influence, which is almost average.

The second group of external determinants which concern municipality level received an average of 3.4 points and this means that their influence was more than mid - score. Among the listed factors, the planning state can be said to have the largest influence with an average rating of 4.41 . Nearly $70 \%$ of respondents concluded that this factor has a very large influence and more than $25 \%$ said it had a big influence. The second highest rating was for the factor named as implementation of the procedures by officials with an average 4.25 . Of the respondents, $53 \%$ assessed its influence as being very big and 30\% assessed it as being big.

While assessing both of the abovementioned factors, the lowest value of the answers from respondents was 2 , which indicates that all respondents agreed that these factors influence land developers' activities but with different intensities.

The next factor whose influence was assessed as big was the economic potential of area because the average rating was 3.77 . Nearly $15 \%$ of respondents said that the impact of this 
factor was very big, almost 50\% of them concluded that it was big and about $35 \%$ stated that it was average. The lowest rating was 3 in this case.

The average rating of the remaining factors, which ranged from 3.0 to 3.7, were ownership (3.66), land supply (3.48), and investment climate in municipality/city (3.33).

In respondents' ratings, the lowest impact was attributed to factors like local community (2.92) and planning fee (2.4). For more than $60 \%$ of respondents, the factor which was defined as local community had a significant importance in activities related to land preparation for building investment; the rest of those questioned assessed its influence as less significant.

In the case of planning fee, $18 \%$ of respondents said that this factor had no influence and almost $40 \%$ concluded that the impact was low; thus, this last factor was said to be the least significant external determinant.

The last two indicators of external determinants received the following ratings: competition among developers -3.4 , migration -2.77 .

A graphical portrayal of responses is presented in Fig. 2.

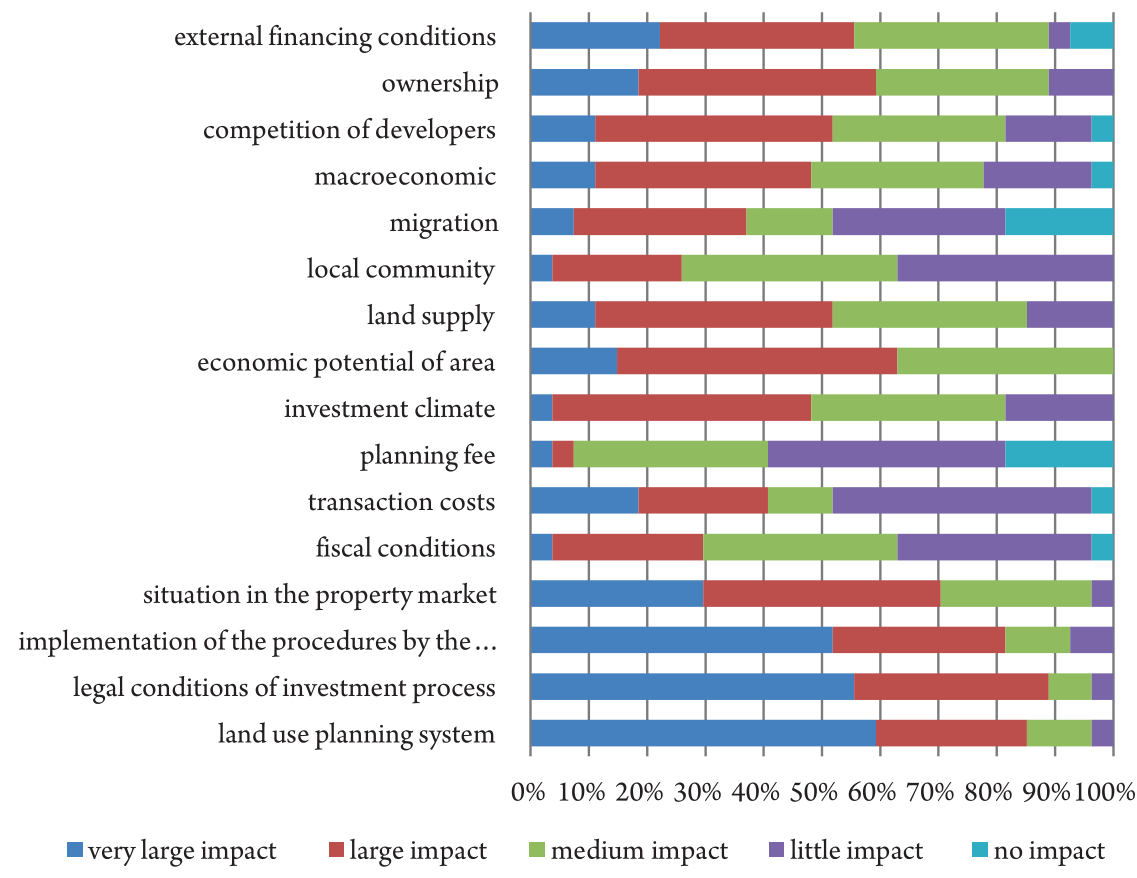

Fig. 2. Structure of the impact of external determinants on land developers' activity

(source: own study based on the research)

The average rating for internal factors is 3.28; thus, there is more than mid - score. The highest rates were for business strategy and financial capital resource, together receiving an average rating of 4.33 . The respondents were on for very big influence (almost $43 \%$ ) of owning of financial capital and for business strategy (nearly 45 . While more of the respondents (over $50 \%$ ) assessed that business strategy has a big influence on land developer's activity. Finally, 
both of these factors were given the highest ratings of all factors. The next factor which was also rated highly was type of development project and its average rate was 3.85 , which meant that it was near to being considered to be very important. In the group of internal determinants having over an average influence on land developer's activity were: company experience (3.77); kind of action in land preparation (3.48); cooperation with company preparing land for construction (3.14). The factors which were assessed below 3.0 were: creation of land banks (2.96); number of employees (2.33); legal form (2.19).

The results are presented in Fig. 3.

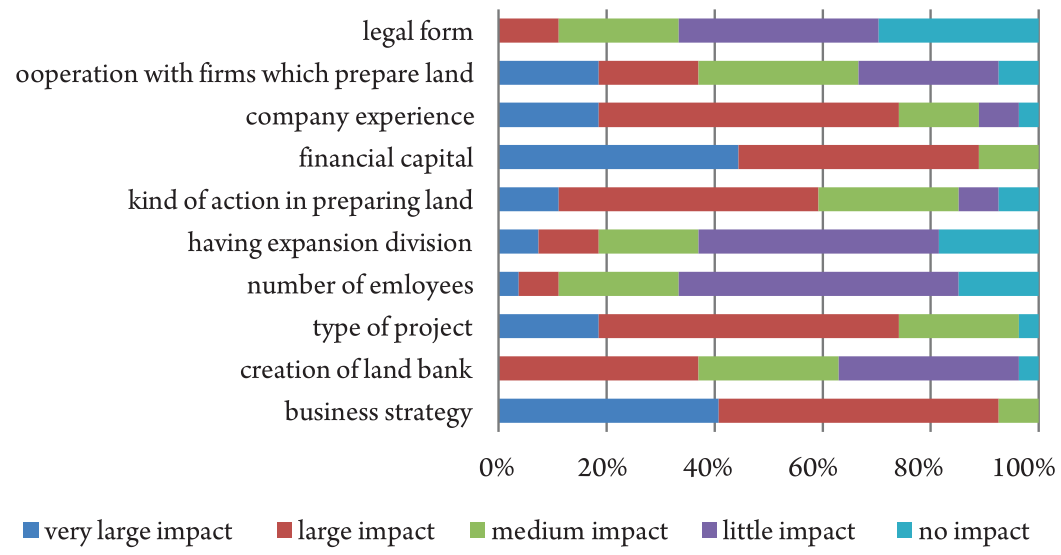

Fig. 3. Structure of the impact of internal determinants (1) on land developers' activity (source: own study based on the research)

The average rating for internal determinants referring to the characteristics of land was 4.0. On this basis, it can be said that respondents considered that the greatest impact on activities depends on the situation related to land. The reason for this may be that of all the analysed determinants, the location was said to be the most important factor of acts related to land preparation for building; this confirmed the intuitive prediction that it would be the primary influence. This is evidenced by the results of the other studies conducted in the context of property development [8]. The informal rule, which appears in various professions in the field of property - location, location, location - was also confirmed [19]. Thus, the location is usually the most important determinant of property value and potential opportunities for sale, such as development projects, especially in difficult market situations. Furthermore, it is based on the investment location, in which investors are subjected to certain external determinants shaped by the municipality/city. The most important of these may include not only the institutional arrangements under the law recognised as a formal periods but especially those that result from the implementation of certain administrative procedures that depend on such the quality and efficiency of public administration. More than $80 \%$ of respondents concluded that the impact of location on land developers' activity is very big, a little less than $20 \%$ concluded that it is large. Thus, the average rating for this factor was 4.81 . The location was assessed to be the most important indicator of all the analysed determinants. Among the 
factors that were also rated highly and received an average rating above 4.0 were: allocation in zoning plan (4.66); the prices of land considered as the effect of economic and legal and physical characteristics and the current market situation (4.48); the access to the public road observed from physical possibility and legal status (4.4); legal status of property was placed in the fifth with an assessment of 4.37. The set of factors evaluated between 4 and 5 constitute the indicators: the need of obtaining planning permission (4.22); size (4.11); construction type (4.0) Among the factors of which the impact has been assessed as more than mid-score are: neighbourhood/environment which is also related to the location (3.96); shape which can affect the efficiency of the construction project (3.85); amenities are the important position in the economic calculation I'm not sure exactly what you mean by this (3.81) and the soil contamination and the need for its regeneration (3.55).

The graphical portrayal of the abovementioned results is presented in Fig. 4.

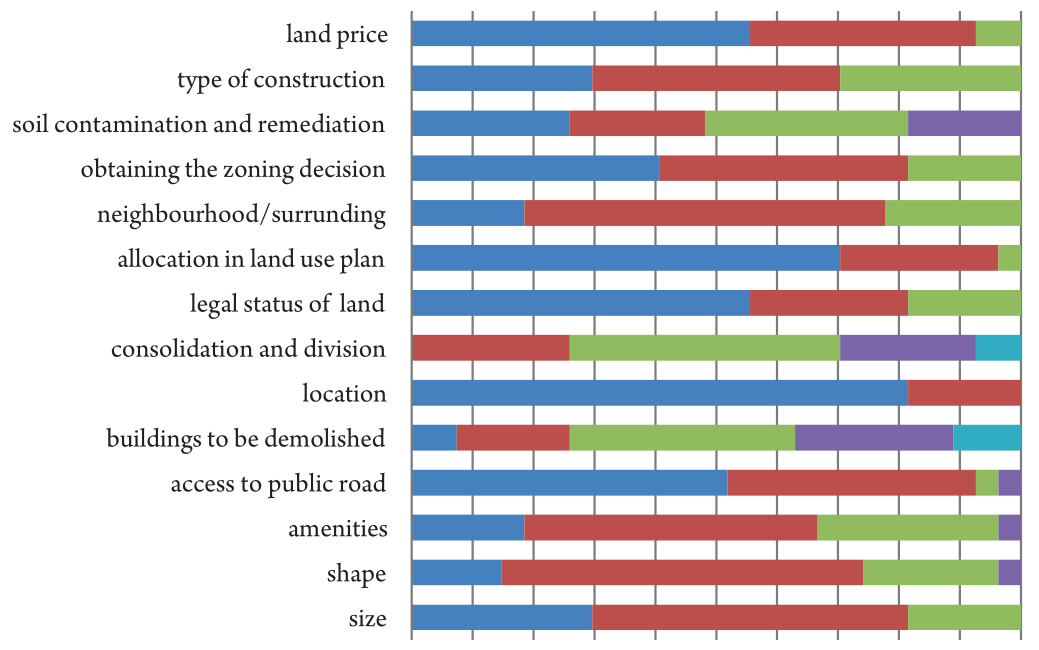

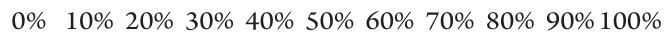

घery large impact $\square$ large impact $\square$ medium impact $\quad$ little impact no impact

Fig. 4. Structure of the impact of internal determinants (2) on land developers' activity (source: own study based on the research)

In conclusion, of the analysed factors, the most important proved to be location (4.88), allocation in zoning plan (4.67), legal conditions of investment process (4.41).

\section{Summary}

The analysis of development activity enables the conclusion that the most desirable areas for development projects are urban spaces and suburbs.

The majority of developers make investments in city centres and they use existing technical infrastructure. Thereby, they limit the risk of failure or increasing costs of the project. 
The respondents said that the land use planning system is the most important factor of all external determinants. The land development for investment is, to a large extend, subject to applicable planning instruments. The different level of coverage areas by zone plan and feasibility of planning decision applicable for area with no plans cause that a developer has a big influence on the way of construction. Moreover, the consequences are exacerbating problems with regard to the land use planning structure in Poland, the formation of settlements without suitable infrastructure solutions, the devastation of the landscape and the occupation of raw land for residential use while there is still a significant amount of brownfields which could be revitalised.

This study is an important step towards the creation of the concept of developers' activity in preparing land for future construction investment. Often, developers' activity is based on using mainly their own experience and trusting their own judgment, requiring decision making within an environment of high risk and little information, valuing the ability to 'control' the process and make maximum use of interpersonal relationships (with lenders, land use officials, investors, and so on); developers possibly base their activities more on these factors than on good market and feasibility analysis. Yet clearly, development activity represents a large share of the supply side of the property market; thus, it is worthy of attention in spite of the world of uncertainty, imperfect information, and generalised functions within which it exists.

Article financed by funds for Badania Statutowe entitled „Rozwój instytucjonalny i funkcjonalny sektora nieruchomości w Polsce", Cracow University of Economics 2018.

\section{References}

[1] Capozza D.R., Helsley R.W., Stochastic City; Journal of Urban Economics 28/1990.

[2] Capozza D.R., Li Y., Optimal land development decisions, Journal of Urban Economics, $51(1) / 2002$.

[3] Capozza D.R. Li Y., The timing and intensity of investment: the case of land, The American Economic Review, 84(4)/1994.

[4] Child P.D., Riddiough T.J., Triantis A.J., Optimal valuation of claims on noisy real assets: theory and application, Real Estate Economics 30/2002

[5] Dąbrowski M., Kirejczyk K., Inwestycje deweloperskie, Twigger, Warszawa 2001.

[6] Drewett R., The developers: decision process, [in:] P.Hall, H.Gracey, R. Drewwett, The Containment of Urban England, Volume II. The Planning System: Objectives, Operations, London 1973.

[7] Dziadosz A., Realizacja przedsięwzięć na krakowskim rynku budowlanym w opiniach deweloperów, Przegląd Budowlany 4/2006.

[8] Evans A.W., The Economics of Residential Location, Palgrave Macmillan, London 1973.

[9] Goodchild R., Munton R., Developer and the Landowner: An Analysis of the British Experience, London 1985. 
[10] Grenadier S.R., The strategic exercise of options: development cascades and overbuilding in real estate, The Journal of Finance 51/1996.

[11] Kaisser E.J., Weiss S.F., Public and Residential Development Process, American Institute of Planners Journal 36/1970.

[12] Kania K., Determinanty dzialalności land deweloperskiej w Polsce - rozprawa doktorska, materiał niepublikowany, UEK 2018, https://r.uek.krakow.pl/jspui/handle/123456789/2794 (access: 15.07.2018)

[13] Majd S., Pindyck R.S., Time to build, option value, and investment decisions, Journal of Financial Economics, 18/1987.

[14] Makhudu T., Real Options and Property Development. Decision making, Real Estate Finance 2011.

[15] Mazurek-Łopacińska K., Badania marketingowe. Teoria i praktyka, Wydawnictwo Naukowe PWN, Warszawa 2005.

[16] Belniak S., Wierzchowski M.W., Pośrednictwo w obrocie nieruchomościami, MWSE, Tarnów 2004.

[17] Mc Namara P., Towards a classification of developers, Urban Law and Policy 6/1983.

[18] Miles M.E., Berens G.L., Real Estate Development. Principles and Process. Fourth Edition, ULI, Chicago 2007.

[19] Pearson T. D., Location! Location! Location! What is location?, The Appraisal Journal $1 / 1991$.

[20] Williams J.T., Real Estate development as an option, Journal of Real Estate Finance and Economics 4/1991. 